\title{
A Study on Problems Faced by Tourists While Travelling Abroad With Respects to South Gujarat
}

\author{
${ }^{1}$ Smit.N.Patel, ${ }^{2}$ Mr. Vivek Ayre \\ ${ }^{1}$ Student, ${ }^{2}$ Assistant Professor, B.V.Patel Institute of Management, Bardoli, INDIA, \\ ${ }^{1}$ smitpatel300@gmail.com, ${ }^{2}$ vivek.ayre@utu.ac.in
}

\begin{abstract}
The survey method used was a questionnaire, which the respondents completed themselves. A statistical package for the social sciences (SPSS) program was used to examine and analyze the findings. The Mann-Whitney $U$ Test is used to identify the problems, because it gives the most accurate estimates of significance. This is the most suited technique because all the data are not normally distributed. The problems for travelling were during both pre- travelling and ongoing travelling. The main problems during ongoing travelling were: cleanliness of toilets, unclear rooms, uncomfortable rooms, noisy neighbors, staff and customers services of hotels/restaurants, losing boarding pass, losing luggage, mosquito bites, staff not respecting customers' "do not disturb" sign and no free Wi-Fi, muscle aches, pains and vomiting. Meanwhile, at pre-travelling the travelers were worried about quality of services and language difficulties, reliability and price/cost.
\end{abstract}

Keyword: tourists, travelers, travelling, abroad, problems, tourism

\section{INTRODUCTION}

"Tourism is a collection of activities, services and industries which deliver a travel experience comprising transportation, accommodation, eating and drinking establishments, retail shops, entertainment businesses and other hospitality services provided for individuals or groups traveling away from home"(UNWTO)[25].

What is tourism? Tourism is defined and understood as the activity of travel and tourism. It is basically a set of travelers' interconnected activities while traveling to a place. And, therefore, tourism as an industry means and covers similar things but from an economic and financial point of view. The tourism industry encompasses all companies that provide products and services designed by tourists at different stages of travel and tourism. Tourism is a very large, vibrant and dynamic and development oriented industry. Tourism is an industry of all business activities that serves travelers when they visit different destinations, such as travel, travel or travel.

Tourism is, in fact, a very widespread industry comprising various sectors or sub-industries that produce and provide a variety of similar and diverse products and services that generate tourism demand and actually make travel and tourism work possible.

\section{LITERATURE REVIEWS}

Pavan kumar (2018), conducted study on problems faced by tourists/ travelers while travelling in India. It aims to find out the reasons for the slowdown in tourist arrivals in comparison with other countries even after various government initiatives. To examine about the various problems faced by tourists/ travelers while travelling different destinations across the India. 96 samples are used to find result. The conclusion of this study was, three clusters of hurdles have emerged by which travelers/tourists are greatly influenced, and these are convenience hurdles, perceived sentimental hurdles and regional hurdles.

Madhavi chockalingam, a. Auroubindo ganesh (2010), conducted study problems encountered by tourists. It aims to identify the problems intensity faced by tourists. 150 samples are used to find result. The conclusion of this research was that the severity of the problem, gender, age, nationality, education, profession, income, geographical location, family size and frequency of tour made. Females, Elders and business people are considered to be perfectionists and hence they express great problems due to corruption, pollution, heavy rush, beggars. It appears that the major problems are the deviations from the arrangements made for their accommodation, visitation, transportation and unexpected expenses.

Indian institute of tourism and travel management (2011), conducted study a study of problems and challenges faced by medical tourists visiting India. Objective this study was to identify the important concerns of medical tourists visiting India Vis-à- vis various service providers in value chain. To identify barriers to service, to identify barriers to the medical tourism industry and to make recommendations to alleviate medical concerns tourists. To identify research issues for further research. The conclusion of this study was like tourism, medical tourism is not one thing. It offers many variants to different segments that come from diverse socio-economic backgrounds, arrive from different geopolitical regions; and demand a range of products. The general assumption is that outbound medical tourism is 
increasing in USA/ UK / Canada and other Western countries and many medical tourists are coming to some developing countries like India, Thailand, Jordan and Singapore for medical procedures that are cost effective. The dynamics of medical tourism, however, is much more intriguing than this simplistic picture.

Marcin Popell (2016), Tourism Market, Disability and Inequality: Conducted a Study on Problems and Solutions. One of the aims of this study is to present the situation of people with disabilities, who are often socially disadvantaged and the findings of this study are discriminated against is that people with disabilities have special needs to participate in their travel and do not travel. There is a lot, but on the other hand they have the same motivation to travel. That is why this still unbelievable field of tourism for people with disabilities is an ongoing trend and many initiatives are being taken in this direction. These actions are intended to reduce the barriers that arise between individuals with special needs and their full participation in tourism activity.

Christina m Angelo, Du, MFF, and TM (2017) studied the extent to which international travelers receive travelrelated illness. The purpose of the study is to provide a current and more accurate estimate of the proportion of travelers receiving illness related to travel. 743 templates are used. The conclusion of this study was that the researcher found that the most comprehensive assessment was available on the proportion of international travelers developing travel-related illness. The data needed will be provided by additional cohort studies to more precisely determine the rate of illness among international travelers; travelers also suffered from diarrhea, gastrointestinal, ovarian, constipation.

Acog Committee Opinion (2009), conducted a study on air travel during pregnancy. One of the aims of this study is to determine the types of problems that pregnant women face when traveling by air. The conclusion of this study was that many women are facing problems such as low blood pressure, blood pressure, reduced aerobic capacity and low cabin moisture like extremity edema.

Corestange conducted a study on Maximiliano's Geoffrey Scull (2014), Exploring Fear of Travel. Study tourist-mindedly. One of the main aims of this research in

\section{RESULT AND ANALYSIS}

a. Mann-Whitney U Test

Airport related problems:

\begin{tabular}{|l|l|l|l|l|l|l|l|l|}
\hline & $\begin{array}{l}\text { Low Internet } \\
\text { Connectivity }\end{array}$ & $\begin{array}{l}\text { Long } \\
\text { Security } \\
\text { Lines }\end{array}$ & $\begin{array}{l}\text { Need More } \\
\text { Traveling } \\
\text { Apps }\end{array}$ & $\begin{array}{l}\text { No Extra } \\
\text { Seats }\end{array}$ & $\begin{array}{l}\text { Power For } \\
\text { The Gadgets }\end{array}$ & $\begin{array}{l}\text { Better Navigation } \\
\text { and instructions }\end{array}$ & $\begin{array}{l}\text { Toilets Need } \\
\text { To Be Clean }\end{array}$ & $\begin{array}{l}\text { Non availability } \\
\text { of food stalls }\end{array}$ \\
\hline $\begin{array}{l}\text { Mann- } \\
\text { Whitney U }\end{array}$ & 1242.000 & 1271.000 & 1264.500 & 1272.000 & 1208.500 & 1217.000 & 1010.500 & 1134.000 \\
\hline Wilcoxon W & 2953.000 & 2306.000 & 2975.500 & 2307.000 & 2919.500 & 2252.000 & 2045.500 & 2169.000 \\
\hline Z & -.450 & -.240 & -.278 & -.230 & -.672 & -.619 & -2.091 & -1.226 \\
\hline $\begin{array}{l}\text { Asymp. Sig. } \\
\text { (2-tailed) }\end{array}$ & 0.653 & 0.810 & 0.781 & 0.818 & 0.502 & 0.536 & $\mathbf{0 . 0 3 7}$ & 0.220 \\
\hline
\end{tabular}
the extreme danger of travel, which often plagues some potential travelers. The conclusions of this chapter were variables such as occupation, education, age, gender or residence, with no direct relationship to travel fears. One of the primary conclusions we get is that business is not a catalyst for risk

\section{RESEARCH METHODOLOGY}

a. Problem Statement: "A Study on Problems Faced by Tourists While Travelling Abroad With Respects to South Gujarat"

b. Objective of the Study:

Primary Objective: The aim of this research is to determine the challenges/problems faced by tourists while travelling abroad.

Secondary Objective: To find out the factors that affecting tourist while travelling abroad.

Descriptive study is used to study the situation. This study helps to describe the situation. A detail descriptive about present situation can be found out by the descriptive study. The Mann-Whitney U Test is used to identify the problems. The Mann-Whitney $U$ test is the true nonparametric counterpart of the t-test and gives the most accurate estimates of significance. This is the most suited technique because all the data's are not normally distributed.

The study area has been designated as South Gujarat as the respondents of the area have more experience of travel and have the habit of traveling periodically. A questionnaire was prepared to collect primary data from the public. The respondents are those who went on tour in the last two years, the sample size was 103 as it was a favorable sample. This is the most convenient sampling technique because the respondents were the ones who volunteered to provide the data. This will definitely reduce the bias in their answers. The sample has more Males (56.3) than females (43.7) whereas. Most of the respondents are educated.

c. Research Hypothesis:

$\mathrm{H}_{0}$ : problems have a positive influence on tourist while they are travelling.

$\mathrm{H}_{1}$ : problems have a Negative influence on tourist while they are travelling. 


\section{Mann-Whitney $U$ Test of Airport related problems}

$\mathrm{H} 0=$ There is no significant association between Gender and problems.

$\mathrm{H} 1=$ There is significant association between Gender and problems.

If the of significant value is less than 0.05 then null hypothesis i.e., H0 is rejected and H1 is accepted, similarly if significant value is more than 0.05 then null hypothesis i.e., $\mathrm{H} 0$ is accepted and $\mathrm{H} 1$ is rejected.

Accommodation related problems:

\begin{tabular}{|l|l|l|l|l|}
\hline & Mann-Whitney U & Wilcoxon W & Z & Asymp. Sig. (2-tailed) \\
\hline Unclear Rooms & & & & 0.018 \\
\hline Rude Staff & 990.000 & 2025.000 & -2.369 & 0.336 \\
\hline Uncomfortable Rooms & 1169.000 & 2204.000 & -0.961 & $\mathbf{0 . 0 4 8}$ \\
\hline Noisy neighbors & 1029.500 & 2064.500 & -1.980 & $\mathbf{0 . 0 4 3}$ \\
\hline No hot water & 1013.500 & 2048.500 & -2.028 & 0.634 \\
\hline Small beds & 1237.500 & 2272.500 & -0.476 & 0.718 \\
\hline Hotel Rules & 1253.500 & 2288.500 & -0.361 & 0.121 \\
\hline No free Wi Fi & 1087.000 & 2111.000 & -1.550 & 0.905 \\
\hline $\begin{array}{l}\text { This doesn't match with the } \\
\text { website brochure }\end{array}$ & 1288.000 & 2323.000 & -0.120 & 0.482 \\
& 1203.500 & 2914.500 & -0.703 & \\
\hline Unexpected fees & & & & 0.619 \\
\hline Faulty electronics & 1234.500 & 2945.500 & -0.847 \\
\hline $\begin{array}{l}\text { Staff not respecting a "Do not } \\
\text { disturb sign" }\end{array}$ & 1291.500 & 2988.500 & -0.193 & 0.926 \\
\hline Not allowing pets" & 1164.000 & 3002.500 & -0.093 & 0.336 \\
\hline Lack of complimentary supplies & 1210.000 & 2199.000 & -0.962 & 0.509 \\
\hline
\end{tabular}

\section{Mann-Whitney U Test of Accommodation related problems}

$\mathrm{H} 0=$ There is no significant association between Gender and problems.

$\mathrm{H} 1=$ There is significant association between Gender and problems.

If the of significant value is less than 0.05 then null hypothesis i.e., H0 is rejected and H1 is accepted, similarly if significant value is more than 0.05 then null hypothesis i.e., $\mathrm{H} 0$ is accepted and $\mathrm{H} 1$ is rejected.

Restaurant/Food related problems:

\begin{tabular}{|l|l|l|l|l|l|l|l|}
\hline & $\begin{array}{l}\text { The restaurant } \\
\text { menu }\end{array}$ & $\begin{array}{l}\text { Unique } \\
\text { selling point }\end{array}$ & $\begin{array}{l}\text { Restaurant } \\
\text { management }\end{array}$ & $\begin{array}{l}\text { Staff and } \\
\text { customer } \\
\text { service }\end{array}$ & Menu price & $\begin{array}{l}\text { Not having } \\
\text { recommendations }\end{array}$ & $\begin{array}{l}\text { Being } \\
\text { unprepared } \\
\text { dishes }\end{array}$ \\
\hline $\begin{array}{l}\text { Mann- } \\
\text { Whitney U }\end{array}$ & 1240.000 & 1280.000 & 1099.500 & 1057.500 & 1161.000 & 1210.000 & 1234.500 \\
\hline Wilcoxon W & 2275.000 & 2315.000 & 2134.500 & 2092.500 & 2872.000 & 2921.000 & 2269.500 \\
\hline Z & -.479 & -.173 & -1.440 & -1.760 & -1.034 & -.663 & -.498 \\
\hline $\begin{array}{l}\text { Asymp. Sig. } \\
\text { (2-tailed) }\end{array}$ & 0.632 & 0.863 & 0.150 & 0.078 & 0.301 & 0.507 & 0.618 \\
\hline
\end{tabular}

\section{Mann-Whitney U Test of Restaurant/Food related problems.}

$\mathrm{H} 0=$ There is no significant association between Gender and problems.

$\mathrm{H} 1=$ There is significant association between Gender and problems.

If the of significant value is less than 0.05 then null hypothesis i.e., $\mathrm{H} 0$ is rejected and $\mathrm{H} 1$ is accepted, similarly if significant value is more than 0.05 then null hypothesis i.e., $\mathrm{H} 0$ is accepted and $\mathrm{H} 1$ is rejected. 
Health related problems:

\begin{tabular}{|l|l|l|l|l|l|l|l|l|}
\hline & Cold & $\begin{array}{l}\text { Mosquito } \\
\text { Bites }\end{array}$ & $\begin{array}{l}\text { Muscle Aches } \\
\text { and Pains }\end{array}$ & Vomiting & The flu & $\begin{array}{l}\text { Altitude } \\
\text { Sickness }\end{array}$ & $\begin{array}{l}\text { Motion } \\
\text { Sickness }\end{array}$ & Sunburn \\
\hline $\begin{array}{l}\text { Mann- } \\
\text { Whitney U }\end{array}$ & $1.128 \mathrm{E} 3$ & 1297.000 & 1097.000 & $1.072 \mathrm{E} 3$ & $1.263 \mathrm{E} 3$ & 1149.000 & 1187.000 & $1.034 \mathrm{E} 3$ \\
\hline Wilcoxon W & $2.162 \mathrm{E} 3$ & 3008.000 & 2808.000 & $2.107 \mathrm{E} 3$ & $2.298 \mathrm{E} 3$ & 2184.000 & 2222.000 & $2.068 \mathrm{E} 3$ \\
\hline Z & -1.242 & -.057 & -1.468 & -1.647 & -.295 & -1.132 & -.857 & -1.871 \\
\hline $\begin{array}{l}\text { Asymp. Sig. } \\
\text { (2-tailed) }\end{array}$ & 0.214 & 0.954 & 0.142 & 0.100 & 0.768 & 0.258 & 0.392 & 0.061 \\
\hline
\end{tabular}

Mann-Whitney U Test of Health related problems.

$\mathrm{H} 0=$ There is no significant association between Gender and problems.

$\mathrm{H} 1=$ There is significant association between Gender and problems.

If the of significant value is less than 0.05 then null hypothesis i.e., $\mathrm{H} 0$ is rejected and $\mathrm{H} 1$ is accepted, similarly if significant value is more than 0.05 then null hypothesis i.e., $\mathrm{H} 0$ is accepted and $\mathrm{H} 1$ is rejected.

Losing related problems:

\begin{tabular}{|c|c|c|c|c|c|c|c|}
\hline & Losing passport & $\begin{array}{l}\text { Losing } \\
\text { Documents }\end{array}$ & $\begin{array}{l}\text { Losing boarding } \\
\text { pass }\end{array}$ & Losing luggage & $\begin{array}{l}\text { Losing credit or } \\
\text { debit Card }\end{array}$ & $\begin{array}{l}\text { Losing Wallets } \\
\text { and Purse }\end{array}$ & Losing Money \\
\hline $\begin{array}{l}\text { Mann-Whitney } \\
\text { U }\end{array}$ & 1280.500 & 1243.500 & 1299.500 & 1297.000 & 1257.000 & 1287.500 & 1187.500 \\
\hline Wilcoxon W & 2991.500 & 2954.500 & 2334.500 & 3008.000 & 2292.000 & 2998.500 & 2898.500 \\
\hline $\mathrm{Z}$ & -.236 & -.519 & -.039 & -.060 & -.355 & -.141 & -.932 \\
\hline $\begin{array}{l}\text { Asymp. Sig. (2- } \\
\text { tailed) }\end{array}$ & 0.813 & 0.604 & $0.969+20$ & $0.952=$ & 0.723 & 0.888 & 0.351 \\
\hline
\end{tabular}

\section{Mann-Whitney U Test of Losing related problems.}

$\mathrm{H} 0=$ There is no significant association between Gender and problems.

$\mathrm{H} 1=$ There is significant association between Gender and problems.

If the of significant value is less than 0.05 then null hypothesis i.e., H0 is rejected and H1 is accepted, similarly if significant value is more than 0.05 then null hypothesis i.e., $\mathrm{H} 0$ is accepted and $\mathrm{H} 1$ is rejected.

b. Frequency:

\section{Purpose of travelling:}

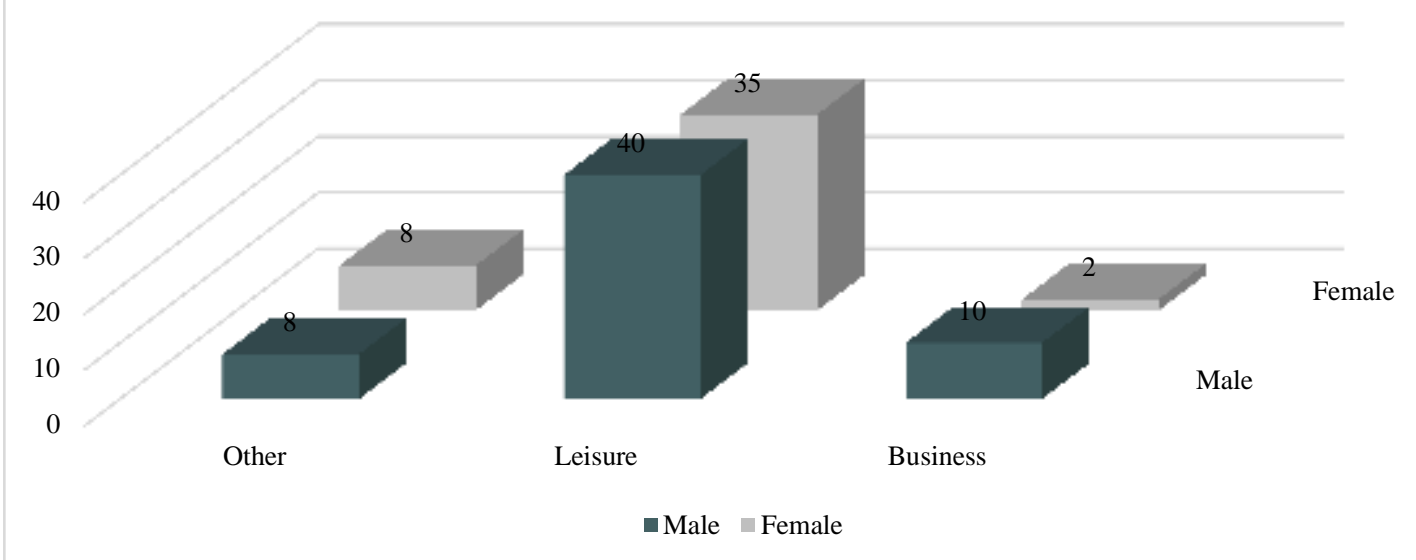


$40 \%$ of the males are prefers to travels for Leisure propose and only $10 \%$ of male are travel for business. In case of female $35 \%$ of female prefers to travel for leisure and $2 \%$ are travel for business purposes.

Frequency of problems faced by travelers while choosing their destinations:

9.What are the most common problems you face while choosing your destination

103 responses

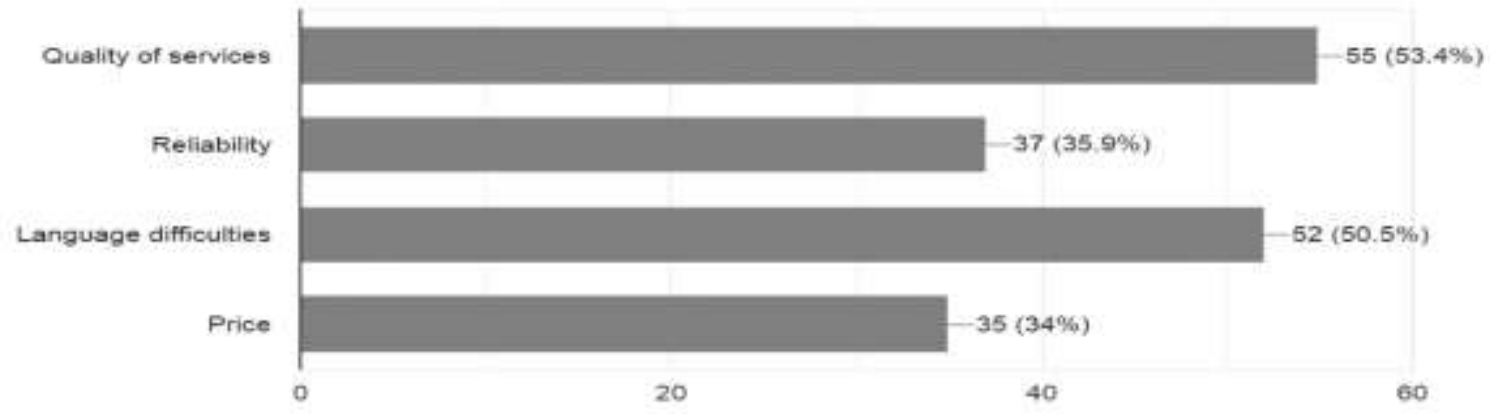

The above graph shows that out of 103 respondents most of the respondent are facing the problem of quality of services and languages difficulties at the time of choosing their destinations. Reliability and price are less affected as compare to quality of services and languages difficulties.

c. Demographic Profile of the study:

43.7

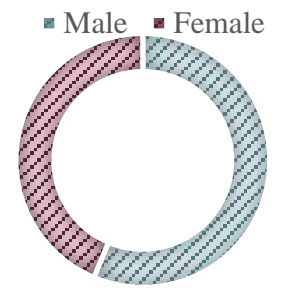
- Less than 24
- Between 24 to 39
- Between 40 to 55
- Over 55

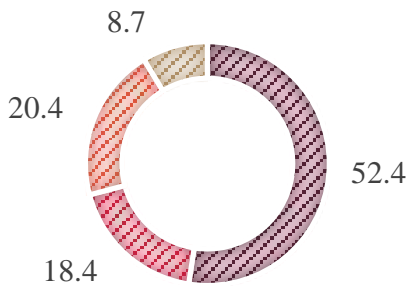

\section{Age Groups}

The pie chart is shows that the majority is between less than $24(52.4 \%), 20.4 \%$ are from 40 to 55 age group, $18.4 \%$ are from 24 to 39 age group, the lowest ratio is from over 55 age group that is $8.7 \%$.

\section{Gander}

The above pie chart shows that $56.3 \%$ respondent are male and the rest are the female (43.7).

n Marrid Unmarrid - Widow Leaving in relation

46.6

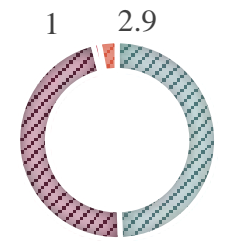

49.5

\section{Marital status}

The above pie chart is shows that the majority of respondents are married (49.5) and the $46.6 \%$ are unmarred. Only $2.9 \%$ are leaving in relation. $1 \%$ is widow.

\section{V.}

MAJOR FINDINGS

- There is significant association between Gender and cleanness of toilets (0.037).

- Also peoples are facing problems like Unclear Rooms, Uncomfortable Rooms, and Noisy neighbors.

- Staff and customers services and sunburn is less affecting as compare to Unclear Rooms, Uncomfortable Rooms, and Noisy neighbors.

- The problems of Losing boarding pass, losing luggage, mosquito bites, staff not respecting "do not disturb sign" and no free Wi-Fi are strongly not affecting to the travelers.

- Muscle aches and pains (0.142) and vomiting (0.100) problems are also affecting but not like other health related problems.

\section{CONCLUSION}

It is a quite a difficult task to determine the different problems faced by travelers/ tourists while they travelling 
to different destinations across different regions of the world. This is because every region has its own customs, traditions, culture which are then all different from each other. The purpose of the study was to understand the common problems faced by travelers from south Gujarat. Through this study, clusters of hurdles have emerged by which travelers/ tourists are greatly influenced, these are airport related problems, accommodation related problems, health related problems, losing problems. This study was confined only to responses of the respondents through the online questionnaire and took into consideration only ablebodied people, and not the people with disabilities. Nonetheless, the findings are still useful to students and researchers who are conducting research in this particular field by applying the same aspects in a wider and deeper sense. In examining the theme region wise to determine specific problems faced by travelers, researchers can use a wider range of variables in determining the problems. The problems experienced by tourists differ depending on numerous factors influencing their tour environment. The problems significantly based on the respondents' gender, age, education, etc.

\section{REFERENCE}

[1] UNWTO, "Definintion of Tourism (UNWTO Definition of Tourism) / What Is Tourism ?," Tugberk Ugurlu, 2010.

[2] P. Kumar, "Problems faced by tourists/ travellers while travelling in India," African Journal of Hospitality, Tourism and Leisure, vol. Volume 7 (3), no. ISSN: 2223-814X , 2018.

[3] A. A. G. Madhavi Chockalingam, "Problems encountered by tourists," BEH-Business and economic horizone, vol. Volume 3, no. 3, pp. pp. 68-72, 2010.

[4] A. K. Mehto1 and S. S. C. G. S. Sunil Kumar Misra2, "Health Problems of the International Travellers Visiting Agra City," INDIAN JOURNAL OF COMMUNITY HEALTH, vol. VOL 29, no. ISSUE NO 02, 2017.

[5] O. W. K. G. C. S. H. S. M. W. F.-J. F. a. T. J. Julia Rack, "Risk and Spectrum of Diseases in Travelers to Popular Tourist Destinations," Journal of travel medicine, vol. VOL 12, no. 5, 2019.

[6] I. I. o. Tourism, "A study of problems and challenges faced by medical tourists visiting India".

[7] T. V. SanjaKovačić*, "AreSerbiantouristsworried?Theeffectof psychologicalfactorsontourists'behaviorbased ontheperceivedrisk," DE GRUYTER, 2019.

[8] *. M. Z. S. M. H. N. I. Rohana Shama, "A Dilemma of Crime and Safety Issues among Vulnerable Travellers in Malaysian Urban Environment," ELSEVIER, 2013.

[9] E. K. B. P. W. R. R. W. P. Kroiß†, "Online Booking On The Net- Problems Issues and Solutions," 1997.

[10] M. Popiel1, "TOURISM MARKET, DISABILITY AND INEQUALITY: PROBLEMS AND SOLUTIONS," 2016.
[11] c. Opinion, "Air travel during pregnancy," TOURISM MARKET, DISABILITY AND INEQUALITY: PROBLEMS AND SOLUTIONS, vol. 132, p. 2, 2018.

[12] G. S. Korstanje Maximiliano1, "EXPLORING THE FEAR OF TRAVEL. STUDY REVEALING INTO TOURIST" MINDS," International Journal of Scientific Management and Tourism, vol. Vol 4, pp. pp 151-155, 2015.

[13] D. A. a. S. Subadra2, "PROBLEMS FACED BY THE PASSENGERS IN SOUTHERN RAILWAYS WITH SPECIAL REFERENCE TO ERODE CITY," ICTACT JOURNAL ON MANAGEMENT STUDIES, vol. VOLUME: 03, no. ISSUE: 04, 201.

[14] D. M. P. E. K. M. E. T. R. M. L. H. C. M. a. M. J. S. P Kristina M. Angelo, "What proportion of international travellers acquire a travel-related illness? A review of the literature," Journal of Travel Medicine, vol. Vol 24, 2017.

[15] R. Cartwright, "Food and waterborne infections associated with package holidays," Journal of Applied Microbiology, 2003.

[16] $\square$. C. F. M. D. P. S. E. S. A. Katherine V. Kortenkampa, "No Hiking Beyond this Point! Hiking Risk Prevention Recommendations in Peer-Reviewed Literature," ELSEVIER, 2017.

[17] M. o. T. (. o. India), "Analyzing the Factors Responsible for Slow-Down in Tourist Arrivals in india," 2010.

[18] s. H. 1. s. a. a. k. Katri vilkman, "Travelers' health problems and behavior:prospective study with post-travel follow-up," Vilkman et al. BMC Infectious Diseases, 2016.

[19] M. Cem, "Decision Making through online reviews : Critical Factors for travelers of selecting a destination before traveling.," 2013.

[20] A. Garg*, "Travel Risks vs Tourist Decision Making: A Tourist Perspective," International Journal of Hospitality \& Tourism Systems, vol. Volume 8, no. Issue 1 June 2015 , 2015.

[21] M. A. H. F. Islam2, "Problems and Prospects of Tourism Industry at Sylhet Region in Bangladesh," IOSR Journal of Research \& Method in Education, vol. Volume 5, no. Issue 5 Ver. III , pp. PP 23-32, 2015.

[22] B. E. Bayih, "Potentials and Challenges of Religious Tourism Development in Lalibela, Ethiopia," African Journal of Hospitality, vol. Volume 7 (4), 2018.

[23] A. B. O.1., "Challenges of Airline Reservation System and Possible Solutions (A Case Study of Overland Airways)," I.J. Information Technology and Computer Science, 2017.

[24] C.R.Kothari, Research Methodology Methods and Techniques, New Delhi: New Age Internaal-(P)Limited.

[24] Introduction: http://www.market-width.com/TourismIndustry.htm

[25] http://www.tugberkugurlu.com/archive/definintion-oftourism-unwto-definition-of-tourism-what-is-tourism [1] 